\title{
Virus-Like Particle Capsid Proteins Encoded by Different L Double- Stranded RNAs of Saccharomyces cerevisiae: Their Roles in Maintenance of M Double-Stranded Killer Plasmids
}

\author{
MOHAMED EL-SHERBEINI, ${ }^{1 \dagger}$ DONALD J. TIPPER,${ }^{2}$ DIANE J. MITCHELL,${ }^{1}$ AND KEITH A. BOSTIAN ${ }^{3 *}$ \\ School of Biological Sciences, Queen Mary College, University of London, London, E1 4NS, United Kingdom ${ }^{1}$; \\ Department of Molecular Genetics and Microbiology, University of Massachusetts Medical School, Worcester, \\ Massachusetts 01605'; and Section of Biochemistry, Division of Biology and Medicine, Brown University, Providence, \\ Rhode Island 02912
}

Received 21 May 1984/Accepted 10 September 1984

\begin{abstract}
The plasmid determinants of killer phenotypes in type $\mathrm{K} 1$ and $\mathrm{K} 2$ killer yeast cells are the 1.9-kilobase (kb) $M_{1}$ and 1.7-kb $M_{2}$ double-stranded RNAs (dsRNAs), respectively. These are dependent for their maintenance and encapsidation, in Saccharomyces cerevisiae virus $\mathrm{ScV}-\mathrm{M}_{1}$ or $\mathrm{ScV}-\mathrm{M}_{2}$ virus-like particles, on the capsid provided by one of a group of moderately related 4.7-kb dsRNAs called $L_{A}$. The $L_{1 A}$ and $L_{2 A}$ dsRNAs found in naturally isolated $K 1$ and $K 2$ killers encode 88-kilodalton $V L_{1 A}-P 1$ and 86-kilodalton $V L_{2 A}-P 1$ capsids, respectively. These are competent for encapsidating homologous $L_{A}$ dsRNAs as well as $M$ dsRNAs. Most strains of $S$. cerevisiae, including killers, contain one of a second group of closely related 4.7-kb dsRNAs called $\mathbf{L}_{\mathrm{BC}}$. These encode their own 82-kilodalton capsid protein, $V \mathbf{L}_{\mathrm{BC}}-\mathrm{P1}$, which, at least in strains containing only $L_{B C}$, encapsidates homologous dsRNA in ScV- $L_{B C}$ virus-like particles. In a $K 1$ killer strain containing both $L_{1 A}$ and $L_{B C}, S c V-M_{1}$ particles contain only $V_{1 A}-P 1$. In such strains it is probable that each virus-like particle contains a single capsid type and that each $L$ dsRNA is encapsidated by a homologous capsid.
\end{abstract}

Most strains of the yeast Saccharomyces cerevisiae contain species of double-stranded RNA (dsRNA) called L (ca. 4.7 kilobases), encapsidated in cytoplasmic virus-like particles (VLPs). These VLPs are called the ScV-L component of the $S$. cerevisiae "virus" ( $\mathrm{ScV})(16)$. The presence of a second dsRNA called M (ca. 1.9 kilobases) is associated with the secretion of a toxin (mycocin) which is lethal to sensitive strains of this and related yeast species $(4,17,27)$. The determinants of type $\mathrm{K} 1$ and $\mathrm{K} 2$ toxin production and of specific immunity to these toxins are the $M_{1}$ and $M_{2}$ dsRNAs. These are found naturally only in cells also containing variants of $L$ called $L_{1}$ and $L_{2}$, respectively (9). They are separately encapsidated in cytoplasmic VLPs called ScV-M $\mathrm{M}_{1}$ and $\mathrm{ScV}-\mathbf{M}_{2} \cdot \mathbf{M}_{\mathbf{2}}$ has little, if any, sequence similarity to $\mathbf{M}_{1}$ (11), whereas $L_{1}$ and $L_{2}$ show limited homology, possibly restricted to near the $5^{\prime}$ termini of their plus strands $(1,2)$.

Purified VLPs from both sensitive and type K1 killer strains contain an 88-kilodalton $(\mathrm{kd})$ protein comprising more than $95 \%$ of the VLP protein, called ScV-P1 $(8,16)$. $\mathrm{ScV}-\mathrm{P} 1$ is identical to $\mathrm{L}-\mathrm{P} 1$, the $88-\mathrm{kd}$ and largest in vitro translation product of denatured L dsRNA (16). ScV-M $\mathrm{M}_{1}$ and $\mathrm{ScV}-\mathrm{L}$ were found to have identical VLP protein patterns (8), and their 88-kd ScV-P1 components gave identical peptide maps (8). ScV-P1 is clearly the major structural component (capsid) of the VLPs in these strains, and dependence of $M_{1}$ dsRNA on L dsRNA must be due, at least in part, to a requirement for a capsid encoded by $L$ dsRNA for $M_{1}$ dsRNA encapsidation.

Several laboratories have recently demonstrated the coexistence of at least two L dsRNA species of similar or identical size in many $S$. cerevisiae strains. Those studied in K1 killers and related strains by Sommer and Wickner (22)

\footnotetext{
* Corresponding author.

$\dagger$ Present address: Division of Biology and Medicine, Brown University, Providence, RI 02912.
}

were called $\mathrm{L}_{\mathrm{A}}, \mathrm{L}_{\mathrm{B}}$, and $\mathrm{L}_{C}$. Liquid hybridization showed $\mathrm{L}_{B}$ and $\mathrm{L}_{C}$ to be ca. $50 \%$ related, although neither showed homology to $L_{A}$. Maintenance of $M_{1}$ dsRNA correlated with the presence of $L_{A}$ which was always the major $L$ dsRNA species in killer strains. Since only $\mathrm{L}_{\mathrm{A}}$ was detectable in $\mathrm{K} 1$ killer strain $K 7$, neither $L_{B}$ nor $L_{C}$ apparently plays an essential role in $M_{1}$ maintenance. In this strain, a single major protein with an estimated size of $81 \mathrm{kd}(22)$ was seen and thus was presumed to be identical to ScV-P1 $(8,16)$. In contrast, VLPs from strains containing only $\mathrm{L}_{B}$ or $\mathrm{L}_{C}$ were found to contain a mixture of protein components within estimated size of 73 to $77 \mathrm{kd} \mathrm{(22).}$

Field et al. (15), using similar strains, identified the major L dsRNA species with $L_{1}(9)$ and called the minor species $L_{a} . L_{a}$ is presumably equivalent to $L_{B}$ or $L_{C}$. $L_{1}$ and $L_{a}$ were differentiated by terminal sequence analysis. $\mathrm{L}_{\mathrm{a}}$ was also found, together with $\mathrm{L}_{2}$, in K2 strains (15).

El-Sherbeini et al. (14), using a technique for rapid isolation of dsRNA, showed that most K1 killer strains contained two species of L-dsRNA which were barely separable by agarose gel electrophoresis. Killer strains K7 and K22 contained only the faster-moving " $\mathrm{L} 2$ " species which is, therefore, presumably equivalent to $\mathrm{L}_{\mathrm{A}}$. Maintenance of both $\mathrm{L} 2$ and $\mathrm{L}_{\mathrm{A}}$, but not " $\mathrm{L} 1$ ", $\mathrm{L}_{\mathrm{B}}$ or $\mathrm{L}_{\mathrm{C}}$, was found to be dependent on MAKIO $(14,22)$. The other five killers tested also contained the slower-moving $L$ dsRNA which presumably equivalent to $\mathrm{L}_{B}$ or $\mathrm{L}_{C}$. It is probable that $\mathrm{L}_{\mathrm{a}}, \mathrm{L} 1, \mathrm{~L}_{\mathrm{B}}$, and $\mathrm{L}_{\mathrm{C}}$ are closely related $\mathrm{L}$ dsRNA species.

We have adopted a nomenclature (24; Table 1$)$ that is an amalgam of the K1-K2 system and the system described by Sommer and Wickner (22). Thus, the L dsRNA in natural killers that encodes ScV-P1 capsid is called $\mathrm{L}_{1 \mathrm{~A}}$, and the equivalent in natural $\mathrm{K} 2$ killers is called $\mathrm{L}_{2 \mathrm{~A}}$. The other species is called $L_{B}, L_{C}$, or (where they have not been differentiated) $\mathrm{L}_{\mathrm{BC}}$. 
TABLE 1. Nomenclature for $L$ dsRNAs and their associated VLP components and translation products

\begin{tabular}{|c|c|c|c|c|}
\hline \multirow{3}{*}{ Source } & \multicolumn{3}{|c|}{$\mathrm{L}_{\mathrm{A}}$ family } & \multirow{3}{*}{$\mathrm{L}_{\mathrm{BC}}$ family } \\
\hline & \multicolumn{2}{|c|}{$\begin{array}{l}\text { Natural association } \\
\text { with: }\end{array}$} & \multirow{2}{*}{$\begin{array}{c}{[\mathrm{HOK}][\mathrm{NEX}]} \\
{[\text { EXL] }} \\
\text { Phenotype }\end{array}$} & \\
\hline & $\mathbf{M}_{1}$ & $\mathbf{M}_{2}$ & & \\
\hline $\begin{array}{l}\text { Sommer and } \\
\text { Wickner } \\
\text { (1982) }\end{array}$ & $\mathbf{L}_{\mathbf{A}}$ & $\mathbf{L}_{\mathbf{A}}$ & $\mathrm{L}_{\mathrm{A}-\mathrm{HN}} \mathrm{L}_{\mathrm{A}-\mathrm{E}}$ & $\mathrm{L}_{\mathrm{B}} \mathrm{L}_{\mathrm{C}} \mathrm{L}_{\mathrm{BC}}$ \\
\hline $\begin{array}{l}\text { Field et al. } \\
\text { (1982) }\end{array}$ & $\mathbf{L}_{1}$ & $\mathrm{~L}_{2}$ & & $\mathbf{L}_{\mathbf{a}}$ \\
\hline $\begin{array}{l}\text { El-Sherbeini } \\
\text { et al. } \\
\text { (1982) }\end{array}$ & & & & "L1" \\
\hline $\begin{array}{l}\text { Proposed: } \\
\text { L dsRNAs }\end{array}$ & $\mathbf{L}_{1 \mathrm{~A}}$ & $\mathrm{~L}_{2 \mathrm{~A}}$ & $L_{A-H N} L_{A-E}$ & $\mathbf{L}_{\mathrm{BC}}$ \\
\hline $\begin{array}{l}\text { Associate } \\
\text { VLPs }\end{array}$ & $\mathrm{ScV}-\mathrm{L}_{1 \mathrm{~A}}$ & $\mathrm{ScV}-\mathrm{L}_{2 \mathrm{~A}}$ & $\mathrm{~L}_{\mathrm{A}-\mathrm{HN}} \mathrm{L}_{\mathrm{A}-\mathrm{E}}$ & $\mathrm{ScV}-\mathrm{l}_{\mathrm{BC}}$ \\
\hline $\begin{array}{l}\text { VLP } \\
\text { Capsids }\end{array}$ & $\mathrm{VL}_{1 \mathrm{~A}}-\mathrm{P} 1$ & $\mathrm{VL}_{2 \mathrm{~A}}-\mathrm{P} 1$ & & $\mathrm{VL}_{\mathrm{BC}}-\mathrm{P} 1$ \\
\hline $\begin{array}{l}\text { Equivalent } \\
\text { transla- } \\
\text { tion } \\
\text { products }\end{array}$ & $\mathrm{L}_{1 \mathrm{~A}}-\mathrm{P} 1$ & $\mathrm{~L}_{2 \mathrm{~A}}-\mathrm{P} 1$ & & $\mathrm{~L}_{\mathrm{BC}}-\mathrm{P} 1$ \\
\hline
\end{tabular}

We now identify $\mathrm{L} 1$ with $\mathrm{L}_{\mathrm{BC}}$, demonstrate that both are contained in VLPs with a single, unique major 82-kd capsid, and show that this capsid is encoded by $\mathrm{L}_{\mathrm{BC}}$ and is identical to L-P2. L-P2 is a previously identified major translation product of denatured total L-dsRNA from K12-1 (3), a strain containing both $L_{1 A}$ and $L_{B C}$. We also confirm the identity of ScV-P1 with L-P1 encoded by $\mathrm{L}_{1 \mathrm{~A}}$ and show that, in strains containing both $\mathrm{L}_{1 \mathrm{~A}}$ and $\mathrm{L}_{\mathrm{BC}}, \mathrm{M}_{1}$ is encapsidated only in ScV-P1 derived from $\mathrm{L}_{1 \mathrm{~A}}$. We also demonstrate that, although $L_{1 A}$ and $L_{2 A}$ share some sequence homology, they encode distinctly different capsid proteins. The $L_{2 A}$ product is the major capsid protein in VLPs of $\mathrm{K} 2$ killer strains containing this dsRNA. A revised nomenclature for $L$ dsRNA translation products and VLP capsid proteins is proposed (Table 1).

\section{MATERIALS AND METHODS}

Yeast strains and media. The yeast strains used in this work and their genotypes, dsRNA contents, and sources are shown in Table 2 . YEPD medium has been previously described (16).

Preparation, fractionation, and analysis of RNAs. Total cellular RNAs and dsRNAs were prepared as previously described $(3,5,8)$. dsRNAs were also fractionated from total cellular RNAs by chromatography on CF11 cellulose (50 $\mu \mathrm{g} / \mathrm{ml}$ [bed volume]) (16). Individual dsRNA species were prepared from total dsRNA by two cycles of preparative agarose slab gel electrophoresis (5). DNase or RNase treatments, with or without $0.4 \mathrm{M} \mathrm{NaCl}$, were as previously described $(3,8)$. Analytical scale reactions contained up to 5 $\mu \mathrm{g}$ of RNA in a total volume of $40 \mu \mathrm{l}$. After nuclease treatment, nucleic acids were recovered by phenol extraction. The phenol phases were extracted twice with aqueous buffer to ensure a quantitative recovery of nucleic acids.

Preparation and analysis of VLPs. Cells for VLP production were grown for $24 \mathrm{~h}$ in $500 \mathrm{ml}$ of YEPD medium with shaking on an orbital shaker. Cells were harvested by centrifugation, washed once with distilled water, and suspended in $5 \mathrm{ml}$ of TES/ME buffer (0.2 M Tris, 0.2 M EDTA, $1.2 \mathrm{M}$ sorbitol, 0.1 M $\beta$-mercaptoethanol [pH 9.2]) and incubated at $37^{\circ} \mathrm{C}$ for $10 \mathrm{~min}$. Cells were washed once with SCE (1 M sorbitol, $0.1 \mathrm{M}$ sodium citrate, $10 \mathrm{mM}$ EDTA [ $\mathrm{pH}$ $5.8]$ ), suspended in $10 \mathrm{ml}$ of SCE plus $750 \mu$ l of zymolase (10 $\mathrm{mg} / \mathrm{ml})(\mathrm{pH} \mathrm{7.5})$, and incubated at $35^{\circ} \mathrm{C}$ for $2 \mathrm{~h}$. Cells were washed with SCE, suspended in $1.5 \mathrm{ml}$ of PKE buffer $(30$ $\mathrm{mM} \mathrm{NaPO}_{4}$ [pH 7.6], $150 \mathrm{mM} \mathrm{KCl}, 10 \mathrm{mM}$ EDTA) per ml of packed cells, and disrupted at $4^{\circ} \mathrm{C}$ by shaking with glass beads for $15 \mathrm{~min}$. Subsequent steps for purification and fractionation of VLPs on sucrose gradients were as previously described $(8)$.

Cell-free protein synthesis and immunoprecipitation. Total cellular RNAs and dsRNAs (native and denatured) were translated in a wheat germ or reticulocyte (18) cell-free protein synthesis system, with L- $\left[{ }^{35}\right.$ S $]$ methionine to label the products as described in previously published procedures (5). Translation products were analyzed by immunoprecipitation, electrophoresis, and fluorography as described previously $(3,5,6)$. The mRNA activities for synthesis of the corresponding immunoprecipitated proteins were determined by densitometry of gel autoradiograms with a JoyceLoebl recording densitometer. Under the conditions employed, the densitometry signal for these proteins was linearly proportional to the concentration of added RNA.

TABLE 2. S. cerevisiae strains ${ }^{a}$

\begin{tabular}{|c|c|c|c|c|c|c|}
\hline \multirow{2}{*}{ Strain } & \multirow{2}{*}{ Genotype } & \multirow{2}{*}{$\begin{array}{c}\text { Killer } \\
\text { phenotype }\end{array}$} & \multicolumn{4}{|c|}{$\begin{array}{l}\text { Relative amts of } \\
\text { dsRNAs }\end{array}$} \\
\hline & & & $\mathbf{M}_{1}$ & $\mathrm{~L}_{1 \mathrm{~A}}$ & $\mathrm{~L}_{\mathrm{BC}}$ & $\mathrm{M}_{2}$ \\
\hline S3 & makl0-1 & $\mathbf{K}^{-} \mathbf{R}^{-}$ & 0 & 0 & 0 & \\
\hline K7-S1 & $\arg 9$ & $\mathbf{K}^{-} \mathbf{R}^{-}$ & 0 & ++ & $\mathbf{0}$ & \\
\hline $\mathrm{K} 12$ & ade $2,-5$ & $\mathrm{~K}_{1}{ }^{+} \mathrm{R}_{1}{ }^{+}$ & + & ++ & 0 & \\
\hline K12-1 & ade2, -5 & $\mathrm{~K}_{1}^{+} \mathrm{R}_{1}^{+}$ & + & ++ & + & \\
\hline & & $\mathrm{K}_{1}+\mathrm{R}_{1}+$ & + & ++ & + & \\
\hline $\mathrm{K} 4(\mathrm{HC})$ & & $\mathbf{K}^{-} \mathbf{R}^{-}$ & 0 & 0 & ++ & \\
\hline K19 & trp5 leul & $\mathrm{K}_{1}^{+} \mathrm{R}_{1}^{+}$ & + & ++ & + & \\
\hline MES-7 & $\begin{array}{c}\mathrm{K} 4(\mathrm{HC}) \times \\
\mathrm{K} 19\end{array}$ & $\mathrm{~K}_{1}+\mathbf{R}_{1}{ }^{+}$ & + & ++ & + & \\
\hline K382-23A & $\begin{array}{l}\text { spoll ura3 } \\
\text { cyh2 ade2 } \\
\text { canl his7 } \\
\text { hom3 }\end{array}$ & $\mathrm{K}_{1}{ }^{+} \mathrm{R}_{1}{ }^{+}$ & $(+)$ & + & + & \\
\hline K396-11A & $\begin{array}{l}\text { spoll ura3 } \\
\text { adel his } 1 \\
\text { leu2 lys } 7 \\
\text { met3 trp5 }\end{array}$ & $\mathbf{K}^{-} \mathbf{R}^{-}$ & 0 & ++ & + & \\
\hline $\mathrm{C} 27$ & MES-7(HC) & $\mathbf{K}^{-} \mathbf{R}^{-}$ & 0 & ++ & + & \\
\hline $\begin{array}{l}\mathrm{C} 26 \\
S 3 \times K 382-23 \mathrm{~A}\end{array}$ & MES-7(HC) & $\mathbf{K}^{-} \mathbf{R}^{-}$ & 0 & 0 & ++ & \\
\hline 3 & $M A K-10$ & $\mathrm{~K}_{1}{ }^{+} \mathrm{R}_{1}{ }^{+}$ & $(+)$ & + & + & \\
\hline 8 & mak-10 & $\mathbf{K}^{-} \mathbf{R}^{-}$ & 0 & 0 & ++ & \\
\hline$\underset{K}{S 3} \times \mathrm{K} 396-11 \mathrm{~A}$ & & & & & & \\
\hline $\begin{array}{l}\mathbf{K} \\
\mathbf{M}\end{array}$ & $M A K-10$ & $\mathbf{K}^{-} \mathbf{R}^{-}$ & 0 & ++ & + & \\
\hline $\begin{array}{l}\text { M } \\
\text { S3 } \times \text { K4 }\end{array}$ & $m a k-10$ & $\mathbf{K}^{-} \mathbf{R}^{-}$ & 0 & 0 & ++ & \\
\hline B & $M A K-10$ & $\mathrm{~K}_{1}{ }^{+} \mathrm{R}_{1}{ }^{+}$ & + & + & ++ & \\
\hline A & $m a k-10$ & $\mathbf{K}^{-} \mathbf{R}^{-}$ & 0 & 0 & ++ & \\
\hline S140 & mktl lysl & $\mathbf{K}^{-} \mathbf{R}^{-}$ & 0 & 0 & $\mathrm{~L}_{\mathrm{B}}$ & \\
\hline 1686 & argl thrl & $\mathbf{K}^{-} \mathbf{R}^{-}$ & 0 & 0 & $\mathrm{~L}_{\mathrm{C}}$ & \\
\hline Y110 & & $\mathrm{K}_{2}{ }^{+} \mathrm{R}_{2}{ }^{+}$ & & $+t$ & 0 & $(+)$ \\
\hline 482 & & $\mathrm{~K}_{2}^{+} \mathrm{R}_{2}^{+}$ & & ++ & + & $(+)$ \\
\hline
\end{tabular}

${ }^{a}$ Abbreviations: $\mathrm{HC}$, heat curing of $\mathrm{M}_{1}$ or of both $\mathrm{M}_{1}$ and $\mathrm{L}_{1 \mathrm{~A}} \cdot \mathbf{0 ,}(+),+$, and ++ , approximate relative amounts of dsRNAs (undetectable, low. moderate, and high, respectively). $\mathrm{L}_{B}$ and $\mathrm{L}_{C}$ have only been separately identified in strains $S 140$ and 1686 , obtained from R. Wickner (20). Strains 3 and $8, \mathrm{~K}$ and $\mathrm{M}$, and $\mathrm{B}$ and $\mathrm{A}$ are haploid derivatives of the indicated crosses. Strains S3, K7, K7-S1, K12, K4, K19, MES-7, K382-23A. and K396-11A were previously described (13). Strains Y110 and 482 were from D. Rogers. The derivation of all other strains is described in the text. 


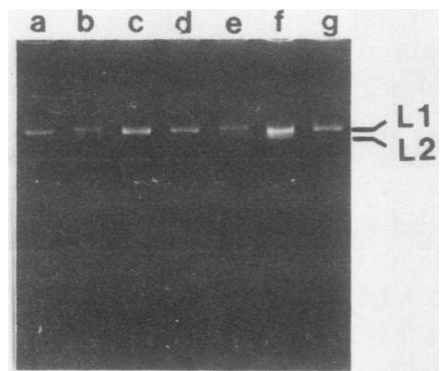

FIG. 1. Gel electrophoretic separation of " $\mathrm{L1}$ " $\left(\mathrm{L}_{\mathrm{BC}}\right)$ and "L2" $\left(L_{1 A}\right)$ dsRNAs in various yeast strains. The rapid total dsRNA isolation procedure previously described (14) was employed. The strains and their dsRNA contents are listed in Table 2. In sequence, they are M. K. 8. C26, C27, B. and A (lanes a to g. respectively). Quantities of dsRNA are too small to allow visualization of $\mathbf{M}$ dsRNA in the killer strain B. L1 is the slightly slower migrating species corresponding to $\mathrm{L}_{\mathrm{BC}}$ : $\mathrm{L} 2$ is the more rapidly migrating species corresponding to $L_{1 A}$.

The preparation of antiserum to the 88-kd capsid (ScV-P1; electrophoretically purified from cells of strain 3/A1) in New Zealand White rabbits, purification of the immunoglobulin fractions, and immunoglobulin characterization have been previously described $(5,8)$.

RNA blot hybridization analysis. Formaldehyde gel electrophoresis and blot hybridization of RNAs were performed as described elsewhere (3). Autoradiographic exposures were made with Kodak XAR-5 film with Dupont Cronex Lightning-Plus intensifier screens. Autoradiograms were optically quantitated with a Joyce-Loebl recording densitometer. At the appropriate autoradiographic exposure, the densitometry signal was linearly proportional to the RNA content, as previously demonstrated (7). dsRNA was hydrolyzed at $95^{\circ} \mathrm{C}$ for $90 \mathrm{~min}$ in $0.05 \mathrm{M}$ Tris ( $\mathrm{pH} 9.5$ )-1 mM EDTA and then labeled with $\mathrm{T} 4$ polynucleotide kinase. Kinase reactions ( 1 to $10 \mu \mathrm{g}$ of dsRNA) occurred at $37^{\circ} \mathrm{C}$ for $45 \mathrm{~min}$ in $100 \mu$ l of the hydrolysis buffer containing, in addition, 10 $\mathrm{mM} \mathrm{MgCl}, 5 \mathrm{mM}$ dithiothreitol, $5 \mathrm{U}$ of kinase, and $1 \mathrm{mCi}$ of crude $\left[\gamma-{ }^{32}\right.$ P]ATP (ICN Nutritional Biochemicals). Unincorporated label was removed by multiple ethanol precipitations of the RNA.

Protein characterization. Peptide maps were obtained by partial proteolysis with Staphylococcus aureus V8 protease through a modification (K. A. Bostian, manuscript in preparation) of the method of Cleveland et al. (12). Lanes containing multiple bands of purified VLP proteins and L dsRNA in vitro translation products were cut out of $10 \%$ acrylamide gels, placed in the sample wells of a second 10 to $15 \%$ sodium dodecyl sulfate-polyacrylamide gel, overlaid with $S$. aureus V8 protease, and electrophoresed into the stacking gel. Hydrolysis was then allowed to occur for 30 min before electrophoresis. Final protease concentrations were within the range from 0.1 to $200 \mu \mathrm{g} / \mathrm{ml}$.

\section{RESULTS}

Construction of homologous pairs of strains differing in $\mathbf{L}_{1 \mathrm{~A}}$ dsRNA content. Several pairs of strains with identical cytoplasms but differing in $\mathrm{L}_{1 \mathrm{~A}}$ and $\mathrm{M}_{1}$ content were obtained by crossing appropriate haploid killers (containing $\mathrm{M}_{1}, \mathrm{~L}_{1 \mathrm{~A}}$, and L1) with strain S3, a maklo mutant lacking all detectable dsRNA (14). Sporulation of the diploid killers gave a 2:2 ratio of segregation of killer (MAK10; retaining $\mathrm{L}_{1 \mathrm{~A}}$ and $\left.\mathrm{M}_{1}\right)$ and maklo non-killer strains (lacking $\mathrm{L}_{1 \mathrm{~A}}$ and $\mathrm{M}_{1}$ ). All retained L1. Such killer-sensitive pairs include strains 3 and
8, strains $\mathrm{K}$ and $\mathrm{M}$, and strains $\mathrm{B}$ and $\mathrm{A}$ (14) (Table 2). A fourth pair of strains, $\mathrm{C} 26$ and $\mathrm{C} 27$, was obtained from killer strains MES-7 (14) by differential heat curing (26). Strain C26 resulted from rigorous treatment, causing the loss of both $M_{1}$ and $L_{1 A}$; milder treatment, leading to the loss of $M_{1}$ only, produced strain C27. Both strains retained L1 (Table 2).

These strains were screened for their L genome content by gel electrophoresis of rapidly isolated total dsRNA (14) (Fig. 1). It can be seen that strains $\mathrm{M}, 8, \mathrm{C} 26$, and A contain only the slower migrating L1, whereas strains $\mathrm{K}, \mathrm{C} 27$, and $\mathrm{B}$ also contain $L_{1 A} . M_{1}$, present in killer strain $B$ (lane $f$ ), comprised only ca. $10 \%$ of the total dsRNA concentration (by mass) and was not visible at these dsRNA concentrations.

Northern blot hybridization analysis of $L$ dsRNAs with $L_{1 A}$ and L1 probes. Denatured total dsRNA from several strains was fractionated by gel electrophoresis and analyzed by Northern blot hybridization (Fig. 2). Two probes were used, L1 $\left(\mathrm{L}_{\mathrm{BC}}\right)$ from strain $\mathrm{M}$ and $\mathrm{L}_{1 \mathrm{~A}}$ from strain $\mathrm{K} 7-\mathrm{S} 1$, a non-killer strain derived from strain $\mathrm{K} 7$ (containing $\mathrm{L}_{1 \mathrm{~A}}$ and $M_{1}[14,22]$ ) by spontaneous loss of $M_{1}$ (Table 2). The L1 probe reacted identically with its homologous dsRNA and with $L_{B}$ and $L_{C}$ dsRNAs (Fig. 2B, lanes $d, b$, and $c$, respectively). All three of these dsRNAs failed to react with the $\mathrm{L}_{1 \mathrm{~A}}$ probe (Fig. $2 \mathrm{~A}$, lanes $\mathrm{d}, \mathrm{b}$, and $\mathrm{c}$ ). The L dsRNA from strain $\mathrm{K} 12$, like that of strain $\mathrm{K} 7-\mathrm{S} 1$, reacted only with the $\mathrm{L}_{1 \mathrm{~A}}$ probe (Fig. 2A, lanes a and e) and so also contains only $L_{1 A}$ (Table 1$)$. This was also true of total dsRNA from strain 2-1 (data not shown). The L dsRNA in strain $\mathrm{K}$, which contains both $L_{1}$ and $L_{1 A}$ species, reacted with both probes (Fig. 2A and B, lanes f) as expected, as did the L dsRNA from strains K12-1 and 3/A1 (data not shown). Strain K12-1 is a subclone of $\mathrm{K} 12$. Although these strains have been separately maintained for ca. 10 years, neither has undergone deliberate genetic manipulation. Thus, the presence of $\mathrm{L} 1\left(\mathrm{~L}_{\mathrm{BC}}\right)$ in $\mathrm{K} 12-1$ and its absence in $\mathrm{K} 12$ is an unexplained result of the separate maintenance of the subclones.

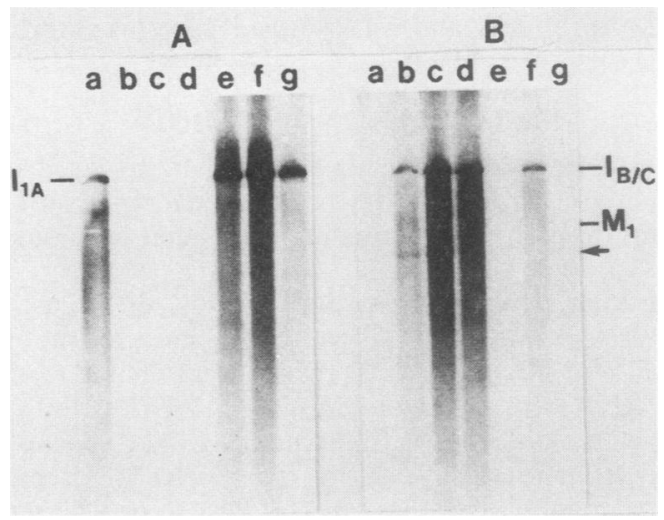

FIG. 2. Northern blot hybridization analysis of total L dsRNAs. Total dsRNAs isolated from the indicated strains were fractionated by gel electrophoresis under denaturing conditions (2) and were detected by hybridization to denatured. fragmented, kinase-labeled RNA probes and autoradiography (see the text). Denatured $L_{1 A}$ $\left(l_{1 A}\right)$ and $L_{B C}\left(l_{B / C}\right)$ migrate identically in this procedure. The migration position of denatured $M_{1}$ is as indicated. (A) Probe $L_{1 A}$ from strain K7-S1. Lanes a, Strain K12 ( $\mathrm{L}_{1 \mathrm{~A}}$ and $\left.\mathrm{M}_{1}\right)$; lane $b$, strain S140 $\left(\mathrm{L}_{\mathrm{B}}\right)$; lane $\mathrm{c}$, strain $1686\left(\mathrm{~L}_{\mathrm{C}}\right)$; lane d, strain $\mathrm{M}\left(\mathrm{L}_{\mathrm{BC}}\right)$; lane e, strain $\mathrm{K}$ 7-S1 $\left(\mathrm{L}_{1 \mathrm{~A}}\right)$; lane $\mathrm{f}$, strain $\mathrm{K}\left(\mathrm{L}_{1 \mathrm{~A}}\right.$ and $\left.\mathrm{L}_{\mathrm{BC}}\right)$; and lane g. strain Y110 $\left(L_{2 A}\right.$ and $\left.M_{2}\right)$. (B) Probe $L_{B C}$ dsRNA from strain $M$. Lanes were as in part $A$. The identity of the minor species of ca. $1 \mathrm{~kb}$ seen in lane $b$ (arrow) is unknown. 


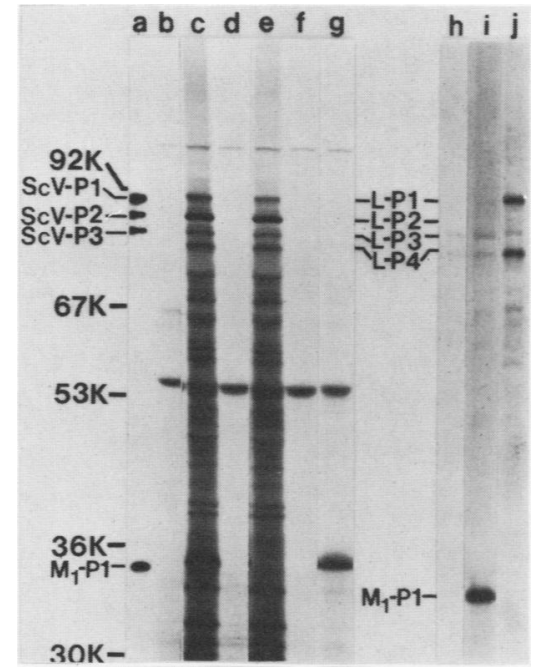

FIG. 3. Comparative sizes of reticulocyte translation products of strain K12-1 dsRNAs and of ScV-P1, ScV-P2, and ScV-P3 VLP protein components derived from the same strain. Translation products, labeled in vitro with $\mathrm{L}-\left[{ }^{35} \mathrm{~S}\right]$ methionine, were fractionated by sodium dodecyl sulfate-polyacrylamide gel electrophoresis and detected by autoradiography (see the text). The migration positions of major translation products L-P1, L-P2, L-P3, and L-P4 and $\mathrm{M}_{1}-\mathrm{P} 1$ are as indicated. Lane a shows Coomassie-stained VLP components ScV-P1, ScV-P2, and ScV-P3, marked with radioactive ink before autoradiography; lanes $b$ through $g$ show total translation products; lanes $h$ to $j$ show products fractionated by immunoprecipitation. Lanes b and c, respectively, show native and denatured strain K12-1 total dsRNA; lanes $d$ and $e$, respectively, show native and denatured L-dsRNA $\left(\mathrm{L}_{1 \mathrm{~A}}\right.$ and $\left.\mathrm{L}_{\mathrm{BC}}\right)$ isolated from strain $\mathrm{K} 12-1$; lanes $\mathrm{f}$ and $g$, respectively, show native and denatured $M_{1}$ isolated from strain $\mathrm{K} 12-1$. Lanes $\mathrm{h}, \mathrm{i}$, and $\mathrm{j}$ show the fraction of the products shown in lane c immunoprecipitated by preimmune, antitoxin, and anticapsid (ScV-P1) immunoglobulin G preparations, respectively.

These data confirmed the marked similarity between $L_{B}$ and $\mathrm{L}_{\mathrm{C}}$ reported by Sommer and Wickner (22) and also demonstrated that they are closely related to the L1 species in strains $\mathrm{M}, \mathrm{K}, 3 / \mathrm{Al}$, and $\mathrm{K} 12-1$. They are all presumed to be members of a relatively homologous L dsRNA subgroup. Following the nomenclature of Sommer and Wickner (22), we shall henceforth refer to them as $\mathrm{L}_{\mathrm{BC}}$ (Table 1). All lack detectable homology to $L_{1 A}$. The $L_{2 A}$ from K2 killer strain Y110 (Fig. 2A and B, lanes $\mathrm{g}$ ) is discussed below.

Complexity of products of translation of $L$ dsRNAs from strain K12-1. Translation of total dsRNA or total L dsRNA from strain K12-1 in the reticulocyte system (18) gave four high-molecular-weight bands, L-P1, L-P2, L-P3, and L-P4 $(88,84,78$, and 75 kd, respectively; Fig. 3, lanes c and e) (3). Many lower-molecular-weight species were also produced. As previously shown (16), L-P1 is identical to ScV-P1, and L-P2 and L-P3 comigrate with two minor, uncharacterized VLP proteins, ScV-P2 and ScV-P3 (Fig. 3, lane a). Only L-P1 and L-P4 were precipitated by antiserum raised against ScV-P1 capsid (anticapsid immunoglobulin G; Fig. 3, lane j). L-P4, originally called L-P2 in the products of translation in the wheat germ system (16), has no comigrating counterpart in VLP preparations.

The relatedness of the total K12-1 L dsRNA translation products was assessed by a two-dimensional modification of the gel electrophoretic peptide mapping technique of Cleveland et al. (12) (Fig. 4). L-P1 and L-P4 clearly gave almost identical terminal hydrolysis products (Fig. 4, panel G)

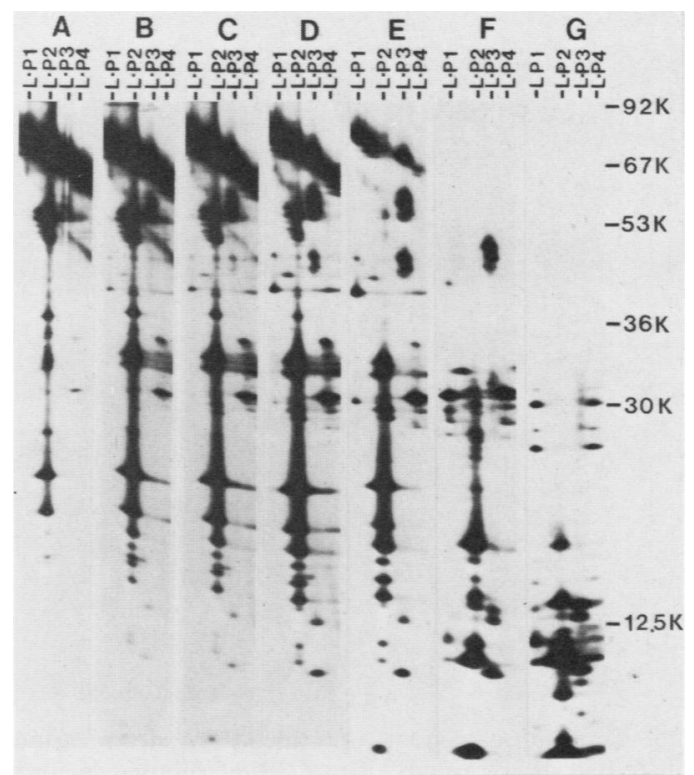

FIG. 4. Peptide maps of L-P1, L-P2, L-P3 and L-P4 derived from reticulocyte translation of strain $\mathrm{K} 12-1$ total denatured dsRNAs. Seven samples of total translation products were fractionated by sodium dodecyl sulfate-polyacrylamide gel electrophoresis (Fig. 3, lane c). Excised gel lanes were loaded laterally into seven separate 10 to $15 \%$ sodium dodecyl sulfate-polyacrylamide gels together with increasing quantities of $S$. aureus V8 protease and were refractionated by sodium dodecyl sulfate-polyacrylamide gel electrophoresis after 30 min of hydrolysis. Each panel shows the autoradiographically detected fragments derived from the $92-$ to $67-\mathrm{kd}$ regions of the original gels. The migration positions of L-P1, L-P2, L-P3, and L-P4 in the first dimension are shown vertically above each panel. The products fractionated diagonally in the $92-$ to $67-\mathrm{kd}$ region represent residual unhydrolysed proteins. Quantities of V8 protease employed in panels $A$ to $G$ were $0.005,0.01,0.025,0.05,0.1,1$, and $20 \mu \mathrm{g}$, respectively.

derived with similar kinetics from partial hydrolysis products, almost all of which are also of identical size. L-P4 must be a fragment of L-P1, presumably lacking ca. $15 \%$ of the L-P1 C-terminal sequence, due to premature termination of translation; that is consistent with its antigentic cross-reactivity.

L-P2 and L-P3 showed no relatedness to each other nor to L-P1 or L-P4. L-P2, a major translation product, was extremely labile to proteolysis (Fig. 4, panel A), and L-P3 had a refractory "core" of large fragments resistant to all but the highest protease concentrations (Fig. 4, panels F and G). The many lower-molecular-weight dsRNA translation products gave patterns which identified most of them as fragments of L-P1, L-P2, or L-P3 (data not shown).

We conclude that strain K12-1 total L dsRNA encodes three major unique in vitro products, L-P1, L-P2, and L-P3. Only the largest of these, L-P1, has previously been identified with an in vivo product (ScV-P1). This identity was confirmed by peptide mapping (see below).

In contrast to the complexity of the products of translation of $L$, the translation of denatured $M_{1}$ produced a single product, the $\mathbf{M}_{1}-\mathrm{P} 1$ preprotoxin (Fig. 3, lane g) $(3,5)$. Antitoxin immunoglobulin $G(5)$ precipitated only $\mathbf{M}_{1}-\mathrm{P} 1$ from the products of translation of total dsRNA (Fig. 3, lane i). Premature termination of translation of denatured dsRNAs in the reticulocyte system appears, therefore, to be restricted to the $\mathrm{L}$ species. 


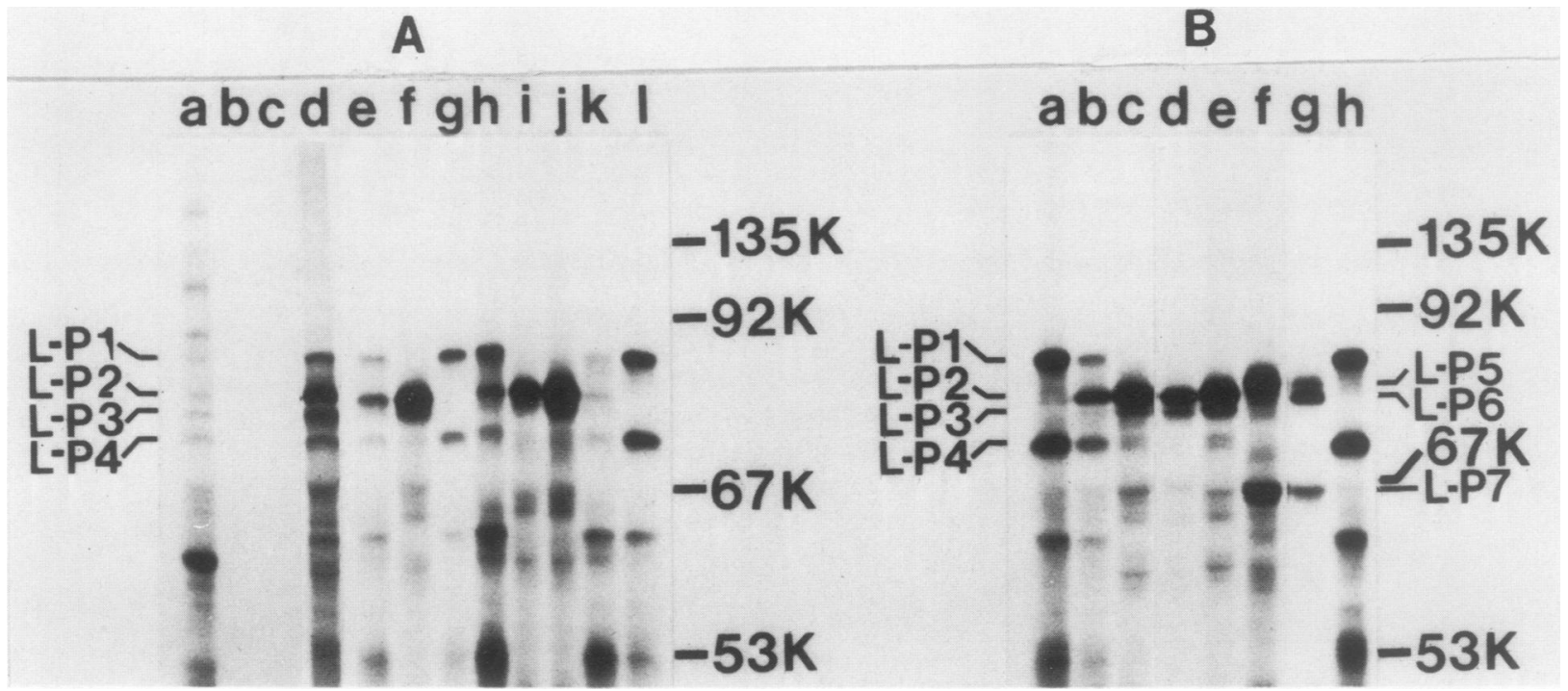

FIG. 5. Translation products of total dsRNAs from various strains. The products of reticulocyte translation of denatured total dsRNAs of the indicated strains, labeled with L- $\left[{ }^{35} \mathrm{~S}\right]$ methionine, were fractionated by sodium dodecyl sulfate-polyacrylamide gel electrophoresis and detected by autoradiography. Migration positions of the major high-molecular-weight products of translation of total $L$ dsRNA ( $L_{1 A}$ plus $L_{B C}$ ) from strain K12-1 (L-P1, L-P2, L-P3, and L-P4) and of total L dsRNA ( $\mathrm{L}_{2 \mathrm{~A}}$ ) from strain Y110 (L-P5, L-P6, and L-P7) are as indicated. Controls show the products of translation of strain K12-1 native total cellular RNA and native total dsRNA (Panel A, lanes a and b, respectively) and the endogenous products of the reticulocyte system (Panel A, lane c). All other lanes show the products of purified, denatured dsRNAs. Panel A: lane d, strain K12-1 ( $L_{1 A}$ plus $\left.L_{B C}\right)$; lane e, strain $C 27\left(L_{1 A}\right.$ plus $\left.L_{B C}\right)$; lane $f$, strain $C 26\left(L_{B C}\right)$; lane $g$, strain $\mathrm{K} 12\left(\mathrm{~L}_{1 \mathrm{~A}}\right)$; lane $h$, strain $\mathrm{K}\left(\mathrm{L}_{1 \mathrm{~A}}\right.$ plus $\left.\mathrm{L}_{\mathrm{BC}}\right)$; lane $\mathrm{i}$, strain $\mathrm{M}\left(\mathrm{L}_{\mathrm{BC}}\right)$; lane $\mathrm{j}$, strain $8\left(\mathrm{~L}_{\mathrm{BC}}\right)$; lane $\mathrm{k}$, strain $3\left(\mathrm{~L}_{1 \mathrm{~A}}\right.$ plus $\left.\mathrm{L}_{\mathrm{BC}}\right)$; and lane $\mathrm{l}$, strain $\mathrm{K} 7-\mathrm{S} 1$ $\left(L_{1 A}\right)$. Panel B: lane a, strain $K 12\left(L_{1 A}\right)$; lane b, strain $B\left(L_{1 A}\right.$ plus $\left.L_{B C}\right)$; lane c, strain A $\left(L_{B C}\right)$ lane d, strain $1686\left(L_{C}\right)$; lane e, strain $S 140$ $\left(\mathrm{L}_{B}\right)$; lane $f$, strain $Y 110\left(\mathrm{~L}_{2 A}\right)$; lane $\mathrm{g}$, strain $482\left(\mathrm{~L}_{2 A}\right.$ plus $\left.\mathrm{L}_{B C}\right)$; and lane $h$, strain $\mathrm{K} 7-\mathrm{S} 1\left(\mathrm{~L}_{1 \mathrm{~A}}\right)$.

Correlation of $L_{1 A}$ with L-P1 and L-P4 and of $L_{B C}$ with L-P2 and L-P3. Translation of denatured L dsRNA from strains containing $\mathrm{L}_{1 \mathrm{~A}}$ alone (K7-S1 and $\left.\mathrm{K} 12\right)$ gave only L-P1 and L-P4 (Fig. 5A, lanes g and 1; Fig. 5B, lanes a and $h$ ), whereas $L$ dsRNA from strains containing only $L_{B}$ (strain S140 [Fig. 5B, lane e]), $L_{C}$ (strain 1686 [Fig. 5B, lane d]), or $\mathrm{L}_{\mathrm{BC}}$ (strains $\mathrm{C} 26, \mathrm{M}$, and 8 [Fig. $5 \mathrm{~A}$, lanes $\mathrm{f}$, $\mathrm{i}$, and $\mathrm{j}$, respectively]; strain $A$ [Fig. $5 B$, lane c]) encoded only $L-P 2$ and L-P3. The L-P2 band was always several-fold more intense than that of L-P3. As expected and as previously seen in strain K12-1 (Fig. 4), translation of total dsRNA from strains containing both $\mathrm{L}_{1 \mathrm{~A}}$ and $\mathrm{L}_{\mathrm{BC}}$ usually gave $\mathrm{L}-\mathrm{P} 1$, L-P2, L-P3, and L-P4 (strains K12-1, C27, K, and 3 [Fig. 5A, lanes d, e, h, and k, respectively]; strain B [Fig. 5B, lane b]). The L-P3 band was always the weakest and was not visible when only small amounts of L dsRNA products were fractionated (e.g., Fig. 5A, lanes e and k). The ratio of L-P2 to L-P1 was always disproportionately high compared with the ratio of $L_{B C}$ to $L_{1 A}$ in the dsRNA translated. Thus, denatured $L_{B C}$ appears to be a much more efficient in vitro messenger than denatured $\mathrm{L}_{1 \mathrm{~A}}$.

$L-P 1$ and $L-P 2$ comigrate with $V L_{1 A}-P 1$ and $V L_{B C}-P 1$, respectively. The revised nomenclature we proposed for VLP capsids (Table $1 ; 24$ ) indicated the particular L dsRNA species encoding the capsid (where identifed) and dropped the Sc prefix to prevent names from becoming too unwieldy. Thus, 88-kd ScV-P1 becomes $\mathrm{VL}_{1 \mathrm{~A}} \mathrm{-P1}$, and the 82-kd capsid species found only in VLPs from strains containing $L_{B C}$ is called $\mathrm{VL}_{\mathrm{BC}}-\mathrm{P1}$, since, as we shall show, these capsids are encoded by $L_{1 A}$ and $L_{B C}$, respectively.

VLPs purified from strains having only $L_{1 A}$ contain only the previously identified 88-kd $\mathrm{VL}_{1 \mathrm{~A}}-\mathrm{P1}$ capsid (Fig. 6A, lanes $c$ and i). Strains containing only $L_{B}, L_{C}$, or $L_{B C}$ (Fig. $6 \mathrm{~A}$, lanes $e, f$, and $d$ plus $h$, respectively) contain only a single $82-\mathrm{kd}$ capsid band $\left(\mathrm{VL}_{\mathrm{BC}}-\mathrm{P} 1\right)$. Because of the rela- tively low copy number of $\mathrm{ScVL}_{\mathrm{BC}}$, these VLP preparations were of variable purity, the many unidentified bands seen on this gel (Fig. 6A) are derived from copurified particulate contaminants (principally ribosomes).

VLPs from strains containing both $\mathrm{L}_{1 \mathrm{~A}}$ and $\mathrm{L}_{\mathrm{BC}}$ contain both 88 - and 82 -kd capsids. Their ratios are roughly proportional to the ratios of $L_{1 A}$ to $L_{B C}$ dsRNA present in the parent strain, which was estimated by densitometry of ethidium bromide-stained gels (Fig. 1). Thus, $\mathrm{L}_{\mathrm{BC}}$ comprises ca. $40 \%$ of the total L dsRNA of strain K382-23A, but only ca. $10 \%$ in strain K396-11A (data not shown). VLPs derived from these strains have corresponding ratios of $\mathrm{VL}_{1 \mathrm{~A}}-\mathrm{P} 1$ and $\mathrm{VL}_{\mathrm{BC}} \mathrm{P1}$ (Fig. 6A, lanes a and b, respectively).

Fractionation of VLP proteins (visualized by staining and marked with radioactive ink) and $L$ dsRNA translation products in the same gel (Fig. 6B) demonstrated that $\mathrm{VL}_{1 \mathrm{~A}^{-}}$ P1 comigrates with L-P1 (strain K12-1; lanes $f, j$, and $n$; strain $\mathrm{K}$; lanes $\mathrm{g}, \mathrm{h}$, and $\mathrm{i}) ; \mathrm{VL}_{\mathrm{BC}}-\mathrm{P} 1$ comigrated with $\mathrm{L}-\mathrm{P} 2$ (all lanes). No prominent VLP component comigrated with L-P3 or L-P4.

Anticapsid $\left(\mathrm{VL}_{1 \mathrm{~A}}-\mathrm{P} 1\right)$ immunoglobulin $\mathrm{G}$ precipitated L-P1 and L-P4 from the products of translation of $\mathrm{L}_{1 \mathrm{~A}}$ from strain K7-S1 (Fig. 6D, lane d), but none of the products of translation of $L_{B C}$ from strain $M$ (Fig. 6D, lane b). This immunoglobulin $G$ also precipitated in vivo-labeled $\mathrm{VL}_{1 \mathrm{~A}}-\mathrm{P} 1$ capsid from total proteins of strain $\mathrm{K} 7-\mathrm{S} 1$ and $\mathrm{K}$ (Fig. $6 \mathrm{E}$, lanes $b$ and $f$ ), but not $V_{L_{B C}-P 1}$ from strains $M$ and $K$ (Fig. $6 \mathrm{E}$, lanes $\mathrm{d}$ and $\mathrm{f})$. The antigenic relatedness of $\mathrm{L}-\mathrm{P} 1$ and $\mathrm{VL}_{1 \mathrm{~A}}-\mathrm{P} 1$ is, therefore, confirmed. Both are antigenically differentiated from $\mathrm{VL}_{\mathrm{BC}}-\mathrm{P} 1$ and L-P2.

Identification of $L-P 1$ with $V L_{1 A}-P 1$ and of $L-P 2$ with $\mathrm{VL}_{\mathrm{BC}}-\mathbf{P 1}$ by peptide mapping. Total $\left[{ }^{35} \mathrm{~S}\right]$ methionine-labeled translation products of denatured $L_{1 A}$ dsRNA were fractionated, along with unlabeled VLP proteins purified from the same strain, by $10 \%$ sodium dodecyl sulfate-polyacrylamide 
gel electrophoresis (Fig. 5B), and the gel regions corresponding to L-P1, L-P4, and $\mathrm{VL}_{1 \mathrm{~A}}-\mathrm{P} 1$ were excised. Gel slices were loaded onto second gels in the presence of increasing quantities of $S$. aureus V8 protease and subsequently fractionated (Fig. 4). The in vitro products were detected by staining with Coomassie blue, and the in vitro products were detected by autoradiography (Fig. 7). Coincident migration and kinetics of production of both partial and terminal hydrolysis products was apparent, confirming both the identity of $\mathrm{VL}_{1 \mathrm{~A}}-\mathrm{P} 1$ and L-P1 and the relationship between L-P1 and L-P4.

Similarly, comigration of the stained V8 protease fragments of $\mathrm{VL}_{\mathrm{BC}}-\mathrm{P} 1$ from VLPs of strain $\mathrm{M}$ and the autoradiographically detected fragments of L-P2 from translation of denatured $L_{B C}$ dsRNA from the same strain (Fig. 8) confirmed the identity of $\mathrm{VL}_{\mathrm{BC}}-\mathrm{P} 1$ and L-P2. Thus, the $\mathrm{L}_{1 \mathrm{~A}}$ and $\mathrm{L}_{\mathrm{BC}}$ dsRNAs in strains $\mathrm{K} 7-\mathrm{S} 1$ and $\mathrm{M}$ are each encapsidated in a homologous capsid. We propose (Table 1) renaming L-P1 and $\mathrm{L}-\mathrm{P} 2$ as $\mathrm{L}_{1 \mathrm{~A}}-\mathrm{P} 1$ and $\mathrm{L}_{\mathrm{BC}}-\mathrm{P} 1$, respectively, to identify them with their L dsRNA genome and VLP capsid counterparts.

Encapsidation of $M_{1}$ dsRNA by $V_{1 A}-P 1$ in a strain containing both $L_{1 A}$ and $L_{B C}$ dsRNAs. The $M_{1}$ dsRNA of strain $2-1$, which contains only $L_{1 A}$, is encapsidated by $V L_{1 A}-P 1$ (8). This must also be true of $M_{1}$ in strain $K 7$. To determine whether $M_{1}$ is encapsidated by both $V_{1 A}-P 1$ and $V L_{B C}-P 1$ in a strain containing both $\mathrm{L}_{1 \mathrm{~A}}$ and $\mathrm{L}_{\mathrm{BC}}$, VLP fractions from strain K382-23A which has an unusually high $\mathrm{L}_{\mathrm{BC}}$ content were assayed by gel electrophoresis and densitometry for the content of total $\mathrm{L}$ dsRNA, $\mathrm{M}_{1}, \mathrm{VL}_{1 \mathrm{~A}}-\mathrm{P} 1$, and $\mathrm{VL}_{\mathrm{BC}}-\mathrm{P} 1$. In addition, the relative contents of $L_{1 A}$ and $L_{B C}$ were estimated by gel electrophoresis as described in the legend to Fig. 1. (Fig. 9).

The lighter VLP peak (fractions 22 to 24 ) contained only $M_{1}$. If one ignores the background of $V L_{B C}-P 1$, which is uncorrelated with the dsRNA peak, it can be seen that ScV- $-M_{1}$ contains only $\mathrm{VL}_{1 \mathrm{~A}}-\mathrm{P} 1$. In the $\mathrm{L}$ dsRNA peak, $\mathrm{L}_{1 \mathrm{~A}}$ (fractions 18 to 21 ) is partially separated from $L_{B C}$ (fractions

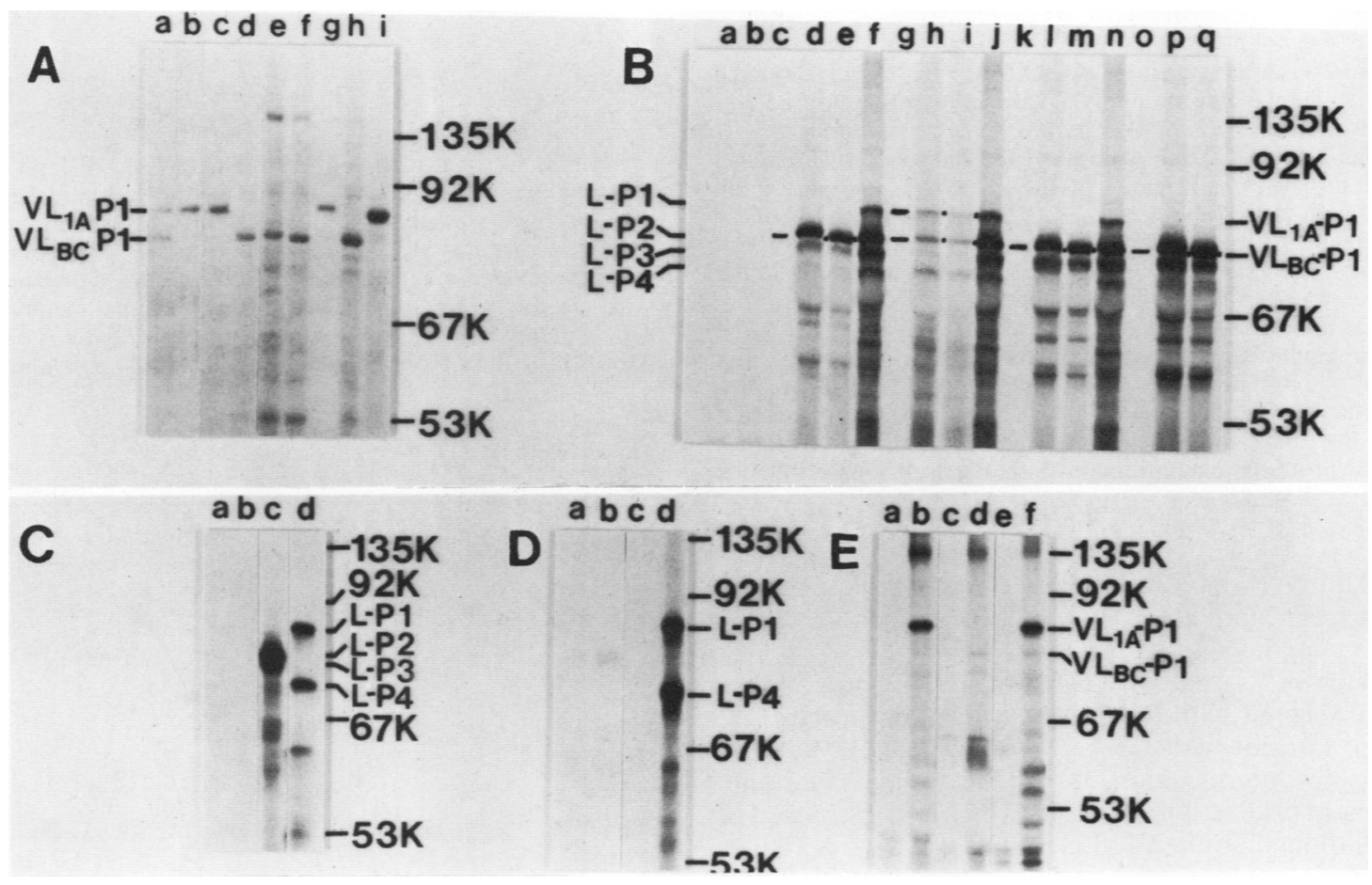

FIG. 6. Comparison of VLP capsid proteins and translation products of $L$ dsRNAs isolated from strains related to type K1 killers. Panel A, sodium dodecyl sulfate-polyacrylamide gel electrophoretic comparison of Coomassie blue-stained VLP capsid proteins. The positions of the major VLP capsid proteins of ScV- $\mathrm{L}_{1 \mathrm{~A}}\left(\mathrm{VL}_{1 \mathrm{~A}}-\mathrm{P1}\right)$ and of ScV- $\mathrm{L}_{\mathrm{BC}}\left(\mathrm{VL}_{\mathrm{BC}}-\mathrm{P1}\right)$ are as follows: lane a, strain $\mathrm{K} 3822-23 \mathrm{~A}\left(\mathrm{~L}_{1 \mathrm{~A}}\right.$ plus $\left.\mathrm{L}_{\mathrm{BC}}\right)$; lane b, strain K396-11A $\left(\mathrm{L}_{1 A}\right.$ plus $\left.\mathrm{L}_{\mathrm{BC}}\right)$; lane $\mathrm{c}$, strain $\mathrm{K} 12\left(\mathrm{~L}_{1 \mathrm{~A}}\right)$; lane d, strain $8\left(\mathrm{~L}_{\mathrm{BC}}\right)$; lane e, strain $\mathrm{S} 140\left(\mathrm{~L}_{\mathrm{B}}\right)$; lane $\mathrm{f}$, strain $1686\left(\mathrm{~L}_{C}\right)$; lane $\mathrm{g}$, strain $\mathrm{K} 4\left(\mathrm{~L}_{1 \mathrm{~A}}\right.$ plus $\left.\mathrm{L}_{B C}\right)$; lane $\mathrm{h}$, strain $\mathrm{M}\left(\mathrm{L}_{\mathrm{BC}}\right)$; and lane $\mathrm{i}$, strain $\mathrm{K} 7-\mathrm{S} 1\left(\mathrm{~L}_{1 \mathrm{~A}}\right)$. Panel $B$, Comigration of capsid proteins and autoradiographically detected denatured L dsRNA translation products derived from the same strains. Translation products of strain K12-1 $\left(L_{1 A}\right.$ plus $\left.L_{B C}\right)$ total denatured dsRNA are shown in lanes $f, j$, and $n$ as markers for $L-P 1, P 2, P 3$, and P4. Other controls are native K12-1 dsRNA products (lane a) and endogeneous reticulocyte products (lane b). Three lanes are shown for each of the four strains. The first contains VLP capsid proteins, the second contains in vitro translation products, and the third contains a mixture of the two. The stained gel and autoradiograph were superimposed, and the positions of the stained major capsid bands $\left(\mathrm{VL}_{1 \mathrm{~A}}-\mathrm{P} 1\right.$ and $\left.V L_{B C}-\mathrm{P} 1\right)$ were marked as bands or as a pair of dots (e.g., lanes $c$ and e, respectively). Lanes c, d, and e, Strain $8\left(L_{B C}\right)$; lanes $g$, h, and i, strain $K\left(L_{1 A}, L_{B C}\right)$; lanes $k, l$, and $\mathrm{m}$, strain $1686\left(\mathrm{~L}_{\mathrm{C}}\right)$; and lanes $o, p$, and $\mathrm{q}$, strain $\mathrm{S} 140\left(\mathrm{~L}_{\mathrm{B}}\right)$. Panel C, Total products of translation of denatured total dsRNA from strain M $\left(\mathrm{L}_{\mathrm{BC}}\right.$; lane $\left.\mathrm{c}\right)$ and strain $\mathrm{K} 7-\mathrm{S} 1\left(\mathrm{~L}_{1 \mathrm{~A}}\right.$; lane d) were fractionated and detected as described in the legend to Fig. 3. Controls are strain $\mathrm{K} 7-\mathrm{S} 1$ native dsRNA (lane a) and reticulocyte endogenous products (lane b). D, Immunological comparison of VLP capsid proteins and $L$ translation products with anticapsid immunoglobulin $G$. Total translation products of denatured $L_{B C}$ (lane b) and denatured $L_{1 A}$ (land d) were precipitated with anticapsid immunoglobulin $\mathrm{G}$ before analysis, as in C. Controls (lanes a and c) are identical to lanes b and d, respectively, except that preimmune immunoglobulin $G$ was used in place of anticapsid immunoglobulin $G$. E, Total proteins, labeled in vivo with $\left.\mathrm{L}-{ }^{35} \mathrm{~S}\right]$ methionine, were analyzed as in $\mathrm{C}$, after immunoprecipitation with preimmune immunoglobulin $\mathrm{G}$ (lanes a, $\mathrm{C}$, and e) or anticapsid immunoglobulin G (lanes b, d, and f). Lanes a and b, Strain K7-S1 ( $\left.\mathrm{L}_{1 \mathrm{~A}}\right)$; lanes $\mathrm{c}$ and d, strain $\mathrm{M}\left(\mathrm{L}_{\mathrm{BC}}\right)$; and lanes $\mathrm{e}$ and $\mathrm{f}$, strain $\mathrm{K}\left(\mathrm{L}_{1 \mathrm{~A}}\right.$ plus $\left.\mathrm{L}_{\mathrm{BC}}\right)$. 


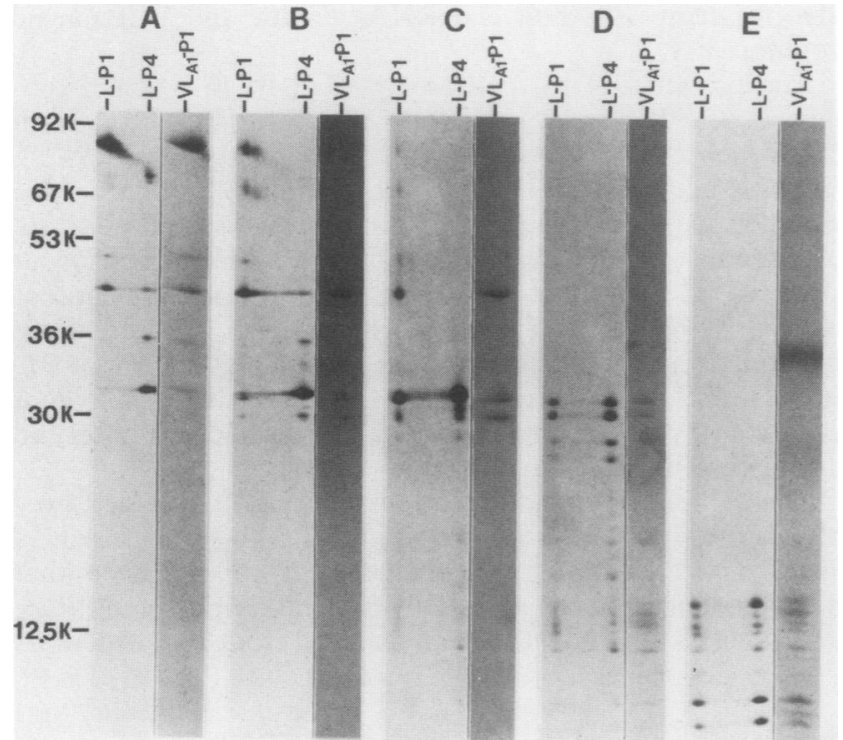

FIG. 7. Comparative peptide maps of $\mathrm{VL}_{\mathrm{A1}}-\mathrm{P} 1$ and $\mathrm{L}_{1 \mathrm{~A}}$ translation products. The labeled products of translation of denatured $\mathrm{L}_{1 \mathrm{~A}}$ dsRNA and unlabeled VLPs from strain K7-S1 (containing VL $L_{1 A^{-}}$ P1) were fractionated by sodium dodecyl sulfate-polyacrylamide ge electrophoresis (Fig. 3). Regions of the gel corresponding to the molecular weight range of interest were excised and loaded laterally onto a second gel (10 to $15 \%$ sodium dodecyl sulfate-polyacrylamide). After hydrolysis for 30 min with $S$. aureus V8 protease, the partial and complete hydrolysis fragments generated were fractionated by electrophoresis. In panels $A$ to $E$, the left half shows the autoradiographically detected fragments of the in vitro product, and the right half shows the Coomassie-stained capsid fragments. Protease amounts were $7.5 \mathrm{ng}$ (lane A), $30 \mathrm{ng}$ (lane B), $0.12 \mu \mathrm{g}$ (lane C), $1.2 \mu \mathrm{g}$ (lane D), and $2.4 \mu \mathrm{g}$ (lane E). At higher concentrations (lanes $\mathrm{D}$ and $\mathrm{E})$, the protease can be seen in stained gels as a pair of bands migrating at ca. $35 \mathrm{kd}$.

19 to 22). Although low resolution precludes absolute assignments, it appears that each L dsRNA is associated with a peak of homologous capsid.

Relationship of $L_{1 A}$ and $L_{2 A}$ dsRNAs. $L_{2 A}$ from $K 2$ killer strain $Y 110$ reacted with the $L_{1 A}$ hybridization probe (Fig. $2 \mathrm{~A}$, lane $\mathrm{g}$ ), but not with the $\mathrm{L}_{\mathrm{BC}}$ probe (Fig. 2B, lane $\mathrm{g}$ ), upon RNA blot hybridization. Densitometry indicated only partial cross-hybridization with $\mathrm{L}_{1 \mathrm{~A}}$, which was estimated at ca. $25 \%$. Although strain $\mathrm{Y} 110$ clearly lacks $\mathrm{L}_{\mathrm{BC}}, \mathrm{K} 2$ killer strain 482 does contain a minor $\mathrm{L}_{\mathrm{BC}}$ component (data not shown).

In vitro translation of denatured $\mathrm{L}_{2}$ from strain $\mathrm{Y} 110$ produced three high-molecular-weight species, L-P5, L-P6, and L-P7, of estimated sizes 84,82 , and $67 \mathrm{kd}$, respectively (Fig. 5B, lane f). L-P5 and L-P7 were the major products. The minor product, L-P6, comigrated with L-P2 ( $\left.\mathrm{L}_{\mathrm{BC}}-\mathrm{P} 1\right)$. A much more intense L-P2 band was seen in the translation products of denatured total dsRNA from strain 482 (Fig. 5B, lane $g$ ) and is presumably $\mathrm{L}_{\mathrm{BC}}-\mathrm{P} 1$ derived from $\mathrm{L}_{\mathrm{BC}}$. Just as in $\mathrm{K} 1$ killer-related strains such as $\mathrm{C} 27$ (Fig. 5A, lane e), a relatively small amount of $L_{B C}$ in strain 482 is responsible for the major in vitro translation product.

The Coomassie-stained capsid protein $\mathrm{VL}_{2 \mathrm{~A}}-\mathrm{P} 1$ from VLPs of strains Y110 and 482 migrated at $84 \mathrm{kd}$ (Fig. 10A, lanes a and $d$, respectively) and thus were clearly differentiated from both $\mathrm{VL}_{1 \mathrm{~A}}-\mathrm{P} 1$ and $\mathrm{VL}_{\mathrm{BC}}-\mathrm{P} 1$ (Fig. 10A, lanes $\mathrm{b}$ and $\mathrm{c}$, respectively). The band of $\mathrm{VL}_{\mathrm{BC}}-\mathrm{P} 1$ in strain 482 was very faint (lane d), which was consistent with the low $L_{B C}$ content

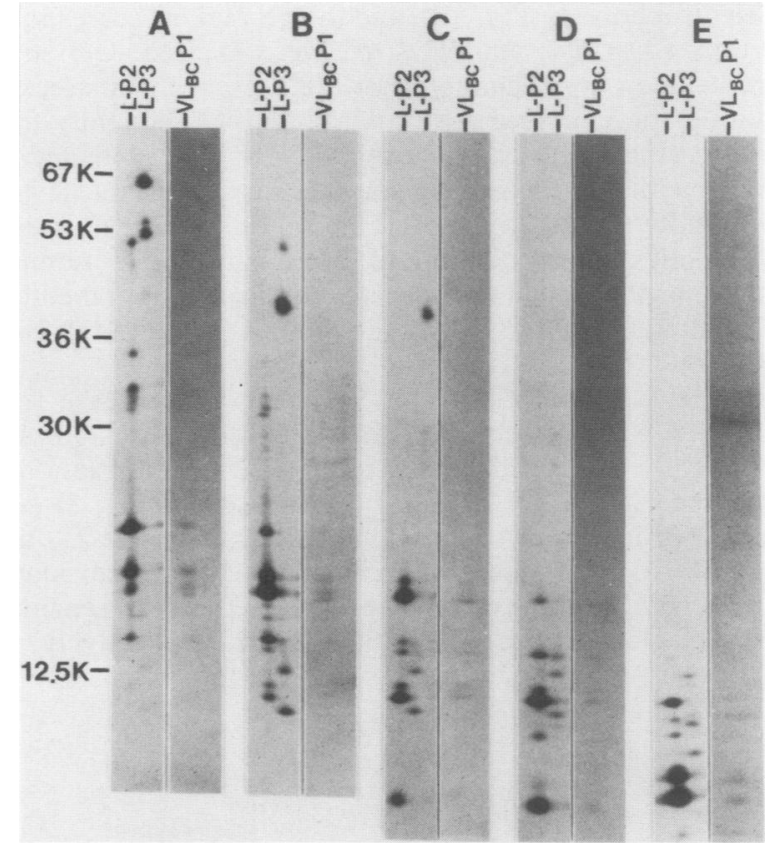

FIG. 8. Comparative peptide maps of $V L_{B C}-P 1$ and $L_{B C}$ translation products. The labeled products of translation of denatured $L_{B C}$ dsRNA and unlabeled VLPs from strain $M$ (containing VL $L_{B C}-P 1$ ) were compared by peptide mapping (Fig. 7). In panels $A$ to $E$, the left half shows the autoradiographically detected fragments of the in vitro products, and the right half shows the Coomassie-stained capsid fragments. Protease amounts were $7.5 \mathrm{ng}$ (lane A), $30 \mathrm{ng}$ (lane B), $0.12 \mu \mathrm{g}$ (lane C), $1.2 \mu \mathrm{g}$ (lane D), $24 \mu \mathrm{g}$ (lane E).

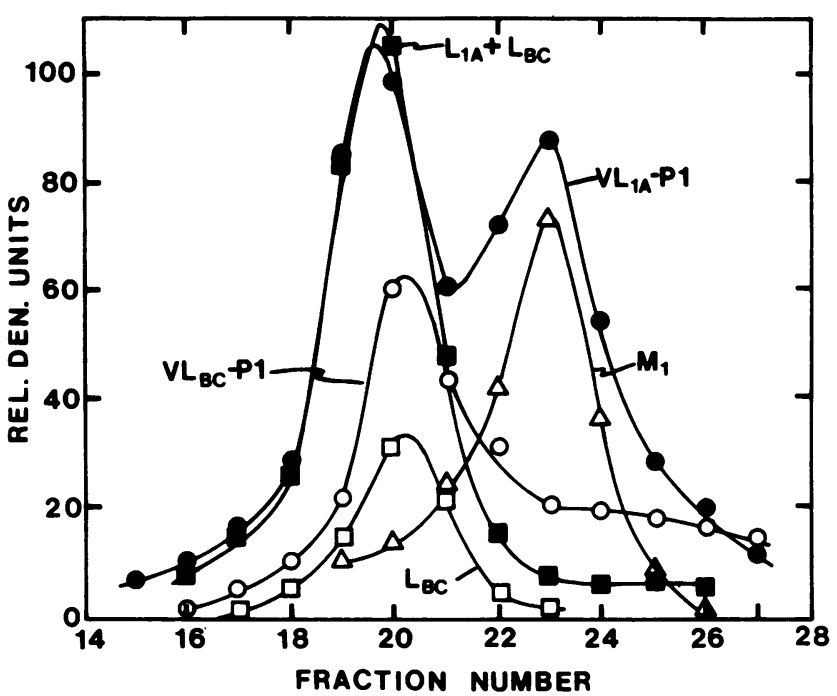

FIG. 9. Capsid proteins in fractionated ScV-L and ScV-M VLPs of $\mathrm{K} 1$ killer strain K382-23A. Crude VLPs from strain K382-23A were refractionated on a 40 to $60 \%$ sucrose gradient (8). Total $\mathrm{L}$ dsRNA $(\square)$ and total $M_{1}$ dsRNA $(\triangle)$ contents of fractions were determined after gel electrophoresis by densitometry of ethidium bromide-stained bands. Similarly, the $\mathrm{L}_{\mathrm{BC}}(\square)$ contents of individual fractions were determined after gel electrophoresis (Fig. 1). The concentrations of $\mathrm{VL}_{1 \mathrm{~A}}-\mathrm{P} 1(\mathrm{O})$ and $\mathrm{VL}_{\mathrm{BC}}-\mathrm{P} 1(\mathrm{O})$ capsid proteins in each fraction were determined by densitometry after sodium dodecyl sulfate-polyacrylamide gel electrophoresis and staining with Coomassie blue. 
of this strain. Cofractionation of stained VLP proteins and of autoradiographically detected dsRNA translation products showed that $\mathrm{VL}_{2 \mathrm{~A}}-\mathrm{P} 1$ comigrated with L-P5 in the products of translation of $\mathrm{Y} 110 \mathrm{~L}_{2 \mathrm{~A}}$ dsRNA (Fig. 10B, lanes e to $\mathrm{g}$ ). This was also true for the relatively weak L-P5 band derived from translation of strain $482 \mathrm{~L}$ dsRNA (Fig. 10B, lanes a to c). As before, the major translation product in this strain comigrates with L-P2 ( $\left.\mathrm{VL}_{\mathrm{BC}}-\mathrm{P} 1\right)$, as for strain K12-1 dsRNA (Fig. 10B, lane d).

The identity of L-P5 and $\mathrm{VL}_{2 \mathrm{~A}}-\mathrm{P} 1$ was demonstrated by comparison of $\mathrm{V} 8$ protease peptide maps (Fig. 11, panels $\mathrm{B}$, $C$, and D). L-P5 is, therefore, identified as $L_{2 A}-P 1$, the in vitro-synthesized equivalent of $\mathrm{VL}_{2 \mathrm{~A}}-\mathrm{P} 1$ capsid protein of ScV-L $\mathrm{L}_{2 \mathrm{~A}}$ VLPs. These peptide patterns also demonstrated the marked difference between $\mathrm{VL}_{1 \mathrm{~A}}-\mathrm{P1}$ (Fig. 11, panels $\mathrm{A}$ and $\mathrm{E}$ ) and $\mathrm{VL}_{2 \mathrm{~A}}-\mathrm{P1}$ (Fig. 11, panels $\mathrm{B}$ and D) after hydrolysis under identical conditions. Neither capsid showed similarity to $\mathrm{L}_{\mathrm{BC}}-\mathrm{P} 1$ (L-P2) derived from translation of $\mathrm{L}_{\mathrm{BC}}$ (Fig. 11, panels $\mathrm{A}$ and E). The relationship of L-P5 to the minor translation products L-P6 and L-P7 (Fig. 10) is unknown.

\section{DISCUSSION}

The naturally isolated $S$. cerevisiae strains and their derivatives employed in these studies are of diverse origin, include wild-type non-killer strains as well as type $\mathrm{K} 1$ and K2 killer strains, and have been independently maintained for many years in laboratories in London (strains $\mathrm{K} 4, \mathrm{~K} 7$, K19, S3, and related strains) (14), New England (strains 3/A1, K12-1, Y110, and 482) (3, 8, 16), Bethesda (strains S140 and 1686) $(21,22)$, and Chicago (strains K382-23A and K396-11A) (Table 2). Nevertheless, with the exception of strains S3, K7, K7-S1, K12, and Y110, all contain L dsRNA species previously called $\mathrm{L1}(14), \mathrm{L}_{\mathrm{B}}(22), \mathrm{L}_{C}(22)$, or $\mathrm{L}_{\mathrm{a}}(15)$ which are indistinguishable by blot hybridization analysis with L1 from strain $M$ as the probe (Fig. 2). These are now called $\mathrm{L}_{\mathrm{BC}}$ (Table 1$)$.
All $\mathrm{L}_{\mathrm{BC}}$ preparations encode major and minor in vitro gene products, $\mathrm{L}_{\mathrm{BC}}-\mathrm{P} 1$ (L-P2) and $\mathrm{L}_{\mathrm{BC}}-\mathrm{P} 2$ (L-P3) $(82$ and $78 \mathrm{kd}$, respectively). $\mathrm{L}_{\mathrm{BC}}-\mathrm{P} 1$ has been identified with $\mathrm{VL}_{\mathrm{BC}}-\mathrm{P} 1$, the 82-kd capsid protein of strain M VLPs. L-P3 is a unique in vitro product. Thus, even though $\mathrm{L}_{B}$ and $\mathrm{L}_{C}$ can be partly distinguished by liquid hybridization analysis (22), these $\mathrm{L}$ dsRNAs apparently belong to a relatively homogeneous mycovirus family, ScV- $\mathrm{L}_{\mathrm{BC}}$.

Cells from strains $3 / \mathrm{A} 1$ and $\mathrm{K} 12-1$, extensively utilized in the characterization of VLP-associated proteins and L dsRNA genes $(3,8,16)$, contain $L_{B C}$ dsRNAs as minor components. Their minor 82- and 78-kd VLP components, ScV-P2 and ScV-P3 (7), have not been characterized. However, ScV-P2 is presumably $\mathrm{VL}_{\mathrm{BC}}-\mathrm{P} 1$ derived from $\mathrm{ScV}$ $\mathrm{L}_{\mathrm{BC}}$, as in strain $\mathrm{K} 382-23 \mathrm{~A}$ (Fig. 9). Although the comigration of ScV-P3 and L-P3 suggests identity, the ratio of ScV-P3 to total VLP protein is not enhanced in strains containing only $\mathrm{L}_{\mathrm{BC}}$, in which $\mathrm{VL}_{\mathrm{BC}}-\mathrm{Pl}$ is the major VLP capsid (Fig. 6A, lanes $d, e, f$, and $h$ ). The significance of L-P3 and the identity of ScV-P3 remain unknown. ScV-P3 could be a persistent contaminant or a nonantigenic fragment of $\mathrm{VL}_{1 \mathrm{~A}}-\mathrm{Pl}$ or might correspond to the dsRNA transcriptase activity present in VLPs of all strains tested $(10,25)$.

The separation of $L_{1 A}$ from $L_{B C}(L 2)$ (Fig. 1) is only seen in preparations that employ a rapid isolation procedure (14). It seems likely that this separation results from residual protein selectively associated with $\mathrm{L}_{\mathrm{BC}}$.

$\mathrm{L}_{\mathrm{A}}$ dsRNAs, initially identified as the major L dsRNA in $\mathrm{K} 1$ killer and related strains tested, are now defined by their dependency on MAK3, MAK10, and PETI8 gene functions $(14,22)$ and by their ability to maintain, exclude, or prevent the exclusion of $\mathbf{M}_{2}$ dsRNA ([HOK], [EXL], and [NEX] phenotypes, respectively; 21, 22). [HOK] is now defined more specifically as the ability to maintain an M dsRNA in a $S K I^{+}$background $(19,24)$. [HOK] activity varies from almost none, as in the $\mathrm{L}_{\mathrm{AE}}$ [EXL] species of strain $\mathrm{AN} 33$ (21), to low as in $L_{2 A}$, to high as in $L_{1 A}\left(L_{A-H N} ; 22\right)$, forming

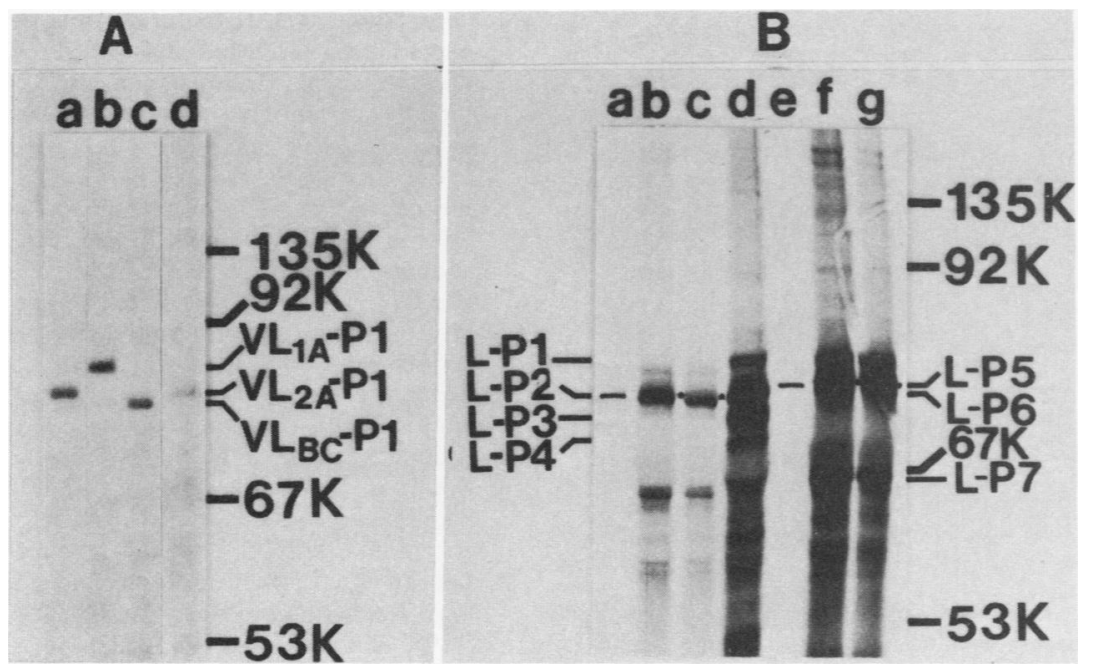

FIG. 10. Comparison of VLP capsid proteins and $\mathrm{L}_{2 \mathrm{~A}}$ translation products from $\mathrm{K} 2$ killer strains $\mathrm{Y} 110$ and 482 . Panel A, Coomassiestained VLP capsid proteins: lane a, strain $482\left(\mathrm{~L}_{2 A}\right.$ plus $\left.\mathrm{L}_{B C}\right)$; lane b, strain $\mathrm{K} 12\left(\mathrm{~L}_{1 \mathrm{~A}}\right)$; lane c, strain $8\left(\mathrm{~L}_{B C}\right)$; lane d, strain $\mathrm{Y} 110\left(\mathrm{~L}_{2 A}\right)$. The migration rates of $\mathrm{VL}_{1 \mathrm{~A}}-\mathrm{P} 1, \mathrm{VL}_{2 \mathrm{~A}}-\mathrm{P} 1$, and $\mathrm{VL}_{\mathrm{BC}}-\mathrm{Pl}$ capsid proteins were as indicated. Panel $\mathrm{B}$, Comigration of stained capsid proteins from VLPs of strains Y110 (lanes e, f, and $g$ ) and 482 (lanes a, b, and c) with the autoradiographically detected translation products of their L dsRNAs. The left-hand lane shown for each strain (a and e) contains only stained VLP capsids marked as a band, the center lane (b and $f$ ) contains the autoradiographically detected translation products, and the right-hand lane (c and g) contains a mixture of both, with the capsid location indicated by a pair of peripheral dots. Lane d contains K12-1 total dsRNA translation products as markers for L-P1, L-P2, L-P3, and L-P4. The major $\mathrm{L}_{2 \mathrm{~A}}$ translation products, L-P5, L-P6 and L-P7, are also indicated. 
an apparent continuum of phenotypes (24). This phenotypic diversity is consistent with the limited cross-hybridization observed between the $\mathrm{L}_{1 \mathrm{~A}}$ of strain $\mathrm{K} 7-\mathrm{S} 1$ and the $\mathrm{L}_{2 \mathrm{~A}}$ of strain Y110 and suggests that the ScV- $\mathrm{L}_{\mathrm{A}}$ mycovirus is a relatively diverse group. This diversity is borne out by comparison of the VLP capsids they encode. L-P1 and L-P5, the major products of translation of $L_{1 A}$ and $L_{2 A}$ dsRNAs, respectively, are now shown to correspond to the $\mathrm{VL}_{1 \mathrm{~A}}-\mathrm{P} 1$ and $\mathrm{VL}_{2 \mathrm{~A}}-\mathrm{P} 1$ capsid proteins of $\mathrm{ScV}-\mathrm{L}_{1 \mathrm{~A}}$ and $\mathrm{ScV}-\mathrm{L}_{2 \mathrm{~A}}$ VLP's, respectively. They differ both in size and in peptide map. Partial cross-reaction between the protein of ScV- $\mathrm{L}_{2 \mathrm{~A}}$ VLPs and anti-VL $\mathrm{L}_{1 \mathrm{~A}}-\mathrm{P} 1$ capsid serum has been previously demonstrated (2). Nevertheless, $\mathrm{L}_{2 \mathrm{~A}}$ can mutate to acquire strong [HOK] activity (27). Peptide mapping of capsids and sequencing of $\mathrm{L}_{\mathrm{A}} \mathrm{cDNAs}$ may eventually determine whether $[\mathrm{HOK}]$ and related phenotypes involved in $\mathbf{M}$ maintenance are determined solely by the structures of encoded capsids.

As in strain 2-1 (8), $M_{1}$ is exclusively encapsidated by $\mathrm{VL}_{1 \mathrm{~A}}-\mathrm{P} 1$ in $\mathrm{K} 1$ strain $\mathrm{K} 382-23 \mathrm{~A}$. Our data suggest that $\mathrm{VL}_{\mathrm{BC}}-\mathrm{P} 1$, also present in this strain, is incorporated homogeneously and exclusively in $\mathrm{ScV}-\mathrm{L}_{\mathrm{BC}}$ VLPs rather than being heterogeneously incorporated as a minor species in all VLPs. Thiele et al. (23) recently demonstrated that $\mathrm{L}_{\mathrm{BC}}$ is located exclusively in very light VLPs which were well separated from ScV- $\mathrm{L}_{1 \mathrm{~A}}$ in VLPs derived from supressive strain S3. The extreme protease sensitivity of $\mathrm{VL}_{\mathrm{BC}}-\mathrm{P} 1$ (Fig. 4) suggests that the very low density of these VLPs reflect proteolytic damage during isolation, perhaps explaining the pattern of three proteins $(76,68$, and $65 \mathrm{kd} ; 23)$ found to be uniquely associated with these light VLPs (23).

An $L_{A}$ appears to be the only plasmid required for $M$ maintenance. ScV- $\mathrm{L}_{\mathrm{BC}}$ is compatible with $\mathrm{ScV}-\mathrm{L}_{1 \mathrm{~A}}, \mathrm{ScV}$ -

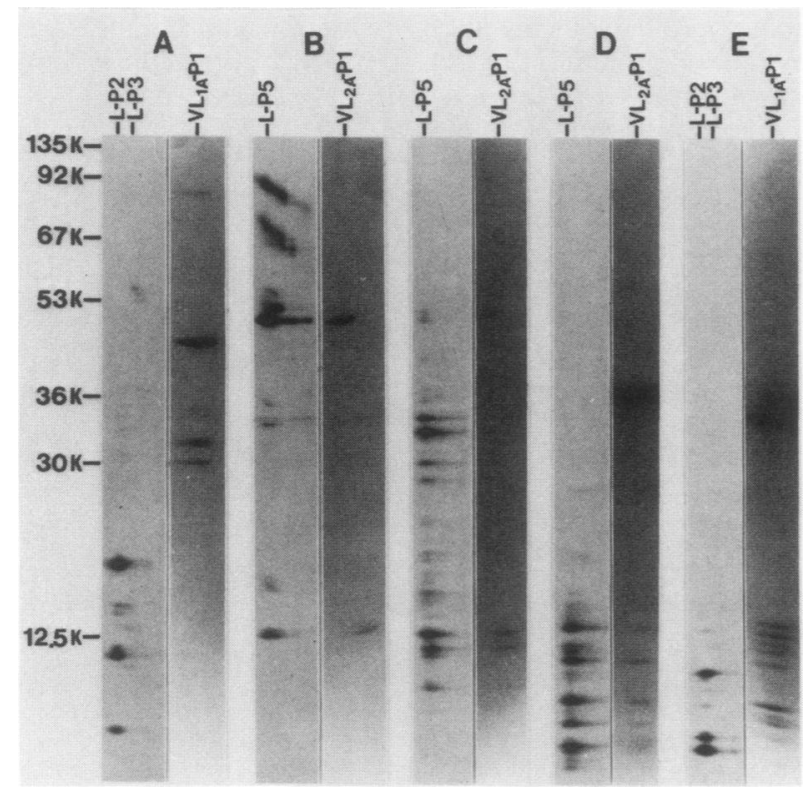

FIG. 11. Comparative peptide maps of $\mathrm{VL}_{1 \mathrm{~A}}-\mathrm{P} 1$, L-P2, L-P3, L-P5, and $V_{2 A}-P 1$. The labeled products of translation of denatured $L_{B C}$ dsRNA from strain M (L-P2 and L-P3; panels A and E) and $L_{2 A}$ from strain 482 (L-P5; panels $B, C$, and D) and unlabeled VLPs from strain K7-1 (containing $\mathrm{VL}_{1 \mathrm{~A}}-\mathrm{P} 1$; panels $A$ and $E$ ) and strain Y110 (containing $\mathrm{VL}_{2 \mathrm{~A}}-\mathrm{P} 1$; panels $\mathrm{B}, \mathrm{C}$, and D) were compared by peptide mapping (Fig. 7). In each panel, the left half shows the autoradiographically detected fragments of in vitro products, and the right half shows the Coomassie-stained capsid fragments. Protease amounts were $0.6 \mu \mathrm{g}$ (lanes A and B), $1.2 \mu \mathrm{g}$ (lane C), and $24 \mu \mathrm{g}$ (lanes D and E).
$\mathrm{L}_{2 \mathrm{~A}}, \mathrm{ScV}-\mathrm{M}_{1}$, and $\mathrm{ScV}-\mathrm{M}_{2}$ but is not required for their maintenance. The increase in ScV- $\mathrm{L}_{\mathrm{BC}}$ content on ScV- $\mathrm{L}_{1 \mathrm{~A}}$ curing by the introduction of a mak-10 allele, however, does suggest competition for some commonly utilized cell component. The dsRNAs of these $S$. cerevisiae viruses are probably replicated by negative-strand synthesis on a separately synthesized plus-strand transcript, as for other eucaryotic dsRNA viruses $(13,24)$. If so, the specificity of dsRNA encapsidation is probably dependent on the recognition, by a capsid, of the sequence or secondary structure at the $3^{\prime}$ terminus of the plus-strand transcripts, as suggested by Brennan et al. (9). Interdependence of nucleation of encapsidation and second-strand synthesis may provide a mechanism for the control of $M$ dsRNA replication by the capsid structure, as implied by [HOK], [NEX], and [EKL] phenotypes $(15,21,22)$.

\section{ACKNOWLEDGMENTS}

This work was supported in part by Public Health Service grant GM 20755 (to D.J.T.) from the National Institutes of Health, Department of Health and Human Services, and by a biomedical research support grant (no. RR05664-15) (to K.A.B.) from the Biomedical Research Support Grant Program, Division of Research Resources, National Institutes of Health.

\section{LITERATURE CITED}

1. Bobek, L. A., J. A. Bruenn, L. J. Field, and K. W. Gross. 1982. Cloning of cDNA to a yeast viral double-stranded RNA and comparison of three viral RNAs. Gene 19:225-234.

2. Bobek, L. A., J. A. Bruenn, L. J. Field, J. D. Reilly, and K. W. Gross. 1983. Cloning of cDNAs homologous to a yeast viral dsRNA, p. 451-456. In R. W. Compans and D. H. L. Bishop (ed.), Double-stranded RNA viruses. Elsevier Science Publishing Co., Inc., New York.

3. Bostian, K. A., V. E. Burn, S. Jayachandran, and D. J. Tipper. 1983. Yeast killer dsRNA plasmids are transcribed in vivo to produce full and partial-length plus-stranded RNAs. Nucleic Acids Res. 11:1077-1097.

4. Bostian, K. A., H. Bussey, Q. Elliot, V. Burn, A. Smith, and D. J. Tipper. 1984. Sequence of the preprotoxin dsRNA gene of type 1 killer yeast: multiple processing events produce a two component toxin. Cell 36:741-751.

5. Bostian, K. A., J. E. Hopper, D. J. Rogers, and D. J. Tipper. 1980. Translational analysis of the killer-associated virus-like particle dsRNA genome of $S$. cerevisiae: M-dsRNA encodes toxin. Cell 19:403-414.

6. Bostian, K. A., S. Jayachandran, and D. J. Tipper. 1983. A glycosylated protoxin in killer yeast: models for its structure and maturation. Cell 32:169-180.

7. Bostian, K. A., J. M. Lemire, and H. O. Halvorson. 1983. Physiological control of repressible acid phosphatase gene transcripts in Saccharomyces cerevisiae. Mol. Cell. Biol. 3:839-853.

8. Bostian, K. A., J. A. Sturgeon, and D. J. Tipper. 1980. Encapsidation of yeast killer double-stranded ribonucleic acids: dependence of M on L. J. Bacteriol. 143:463-470.

9. Brennan, V., L. Field, P. Cizdziel, and J. A. Bruenn. 1981. Sequence of the $3^{\prime}$ ends of yeast dsRNA: proposed transcriptase and replicase initiation sites. Nucleic Acids Res. 9:4007-4021.

10. Bruenn, J., L. Bobek, V. Brennan, and W. Held. 1980. Yeast viral RNA polymerase is a transcriptase. Nucleic Acids Res. 8:2985-2997.

11. Bussey, H. 1981. Physiology of killer factor in yeast. Adv. Microbial. Physiol. 22:93-112.

12. Cleveland, D. W., S. G. Fisher, M. W. Kirschner, and U. K. Laemmli. 1977. Peptide mapping by limited proteolysis in sodium dodecyl sulfate and analysis by gel electrophoresis. J. Biol. Chem. 252:1102-1106.

13. Compans, R. W., and D. H. L. Bishop (ed). 1983. Double stranded RNA viruses. Elsevier/North-Holland Publishing Co., New York. 
14. El-Sherbeini, M., E. A. Bevan, and D. J.Mitchell. 1982. Two biochemically and genetically different forms of L dsRNA of Saccharomyces cerevisiae exist: one form, L2, is correlated with the [HOK] plasmid. Curr. Genet. 7:63-68.

15. Field, L. J., L. Bobek, V. Brennan, J. D. Reilly, and J. Bruenn. 1982. There are at least two yeast viral double-stranded RNAs of the same size: an explanation for viral exclusion. Cell 31:193-200.

16. Hopper, J. E., K. A. Bostian, L. B. Rowe, and D. J. Tipper. 1977. Translation of the L-species dsRNA genome of the killer-associated virus-like particles of Saccharomyces cerevisiae. J. Biol. Chem. 252:9010-9017.

17. Palfree, R., and H. Bussey. 1979. Yeast killer toxin: purification and characterization of the protein toxin from Saccharomyces cerevisiae. Eur. J. Biochem. 93:487-493.

18. Pelham, H. R. B., and R. J. Jackson. 1976. An efficient mRNAdependent translation system from reticulocyte lysates. Eur. J. Biochem. 67:247-256.

19. Ridley, S. P., S. S. Sommer, and R. B. Wickner. 1984. Superkiller mutations in $S$. cerevisiae suppress exclusion of $\mathrm{M}_{2}$ double-stranded RNA by L-A-HN and confer cold sensitivity in the presence of $M$ and L-A-HN. Mol. Cell. Biol. 4:761-770.

20. Rogers, D., and E. A. Bevan. 1978. Group classification of killer yeasts based on cross-reactions between strains of different species and origin. J. Gen. Microbiol. 105:199-202.

21. Sommer, S. S., and R. B. Wickner. 1982. Co-curing of plasmids affecting killer double-stranded RNAs of Saccharomyces cerevisiae: [HOK], [NEX], and the abundance of $L$ are related and further evidence that $\mathrm{M}_{1}$ requires $L$. J. Bacteriol. 150:545-551.

22. Sommer, S. S., and R. B. Wickner. 1982. Yeast L dsRNA consists of at least three distinct RNAs; evidence that the non-Mendelian genes [HOK] [NEX] and [EXL] are on one of these dsRNAs. Cell 31:429-441.

23. Theile, D. J., E. M. Hannig, and M. J. Leibowitz. 1984. Multiple L double-stranded species of Saccharomyces cerevisiae: evidence for separate encapsidation. Mol. Cell. Biol. 4:92-100.

24. Tipper, D. J., and K. A. Bostian. 1984. Double-stranded ribonucleic acid killer systems in yeast. Microbiol. Rev. 48:125-156.

25. Welsh, J. D., and M. J. Leibowitz. 1980. Transcription of killer virion double-stranded RNA in vitro. Nucleic Acids Res. 8:2365-2375

26. Wickner, R. B. 1983 . Killer systems in Saccharomyces cerevisiae: three distinct modes of exclusion of $\mathrm{M}_{2}$ double-stranded RNA by three species of double-stranded RNA, $M_{1}, L-A-E$, and L-A-HN. Mol. Cell. Biol. 3:654-661.

27. Woods, D. R., and E. A. Bevan. 1968. Studies on the nature of the killer factor produced by Saccharomyces cerevisiae. J. Gen. Microbiol. 51:115-126. 